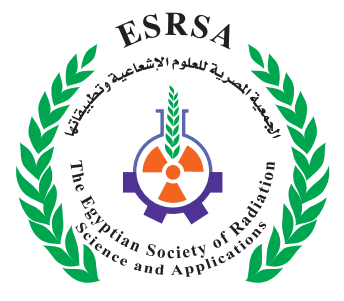

J. Nucl. Tech. Appl. Sci., Vol. 8, PP. 29 : 34 (2020)

\title{
Strategic and Sustainable Land Use Planning of Coastal Sites in Egypt
}

\section{Samia Morsy}

Received: 05/12/2019

Accepted: 09/02/2020

E.mail:samiawm@hotmail.com

\section{KEYWORDS}

Coastal Sites, Land

Use Planning,

Nuclear Power Plants,

Sustainability, Future

Generations.

\section{ABSTRACT}

Coasts and sea fronts are some of the most desired destinations on Earth. In Egyptian contemporary urban planning there are two ways to deal with sea fronts: 1 . To remain the property of the state and let them to private companies/developers who create services and make them accessible to the public in exchange for a certain fee. 2 . To sell them to private developers who make them private and thus get used by a limited number of people who either own a property in the development and their guests or are hiring in it. The cities of Alexandria and Mersa Matruh represent alternative number one; the coast is visible and accessible to the public. Between Alexandria city and Mersa Matruh city, alternative two was adopted; the sea is private belonging to private resorts. The public is not able to access the sea and sometimes not even see it from afar. Furthermore, land use can hardly be changed in the future, even if the need for energy projects arises.

The objective of this paper is to suggest a new alternative, which is a mix between the two alternatives, in order to save what is remaining from the North coast (Mediterranean Sea), the East coast (Red Sea) and the Sinai Peninsula before being transformed into private gated communities. So that, seas remain accessible to all citizens, tourists and sites for the construction of nuclear power plants and other renewable energy projects remain a possibility for future generations. 


\section{DEFINITIONS}

Lease: A legal agreement by which the owner of a building, a piece of land, or something such as a car allows someone else to use it for a period in return for money (Collins English Dictionary).

Resort: A group of buildings gated together by a fence and security system, where only the owners and their guests can enter. A resort is a vacation place, often with food and entertainment (Google).

Scenic route: A specially designated road or waterway that travels through an area of natural or cultural beauty. The designation is usually determined by a governmental body, such as a Department of Transportation or a Ministry of Transport (Wikipedia).

\section{INTRODUCTION}

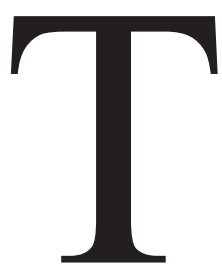

his paper suggests that owning the coasts by the state is strategic, so that coasts remain a public property on which national projects can be erected, like nuclear power plants and renewable energy projects or just being beaches for the use of the public. At the present time in Egypt, coastal sites are being sold to private real estate developers without leases to become touristic private gated communities where only an exclusive number of people can use. Except for Alexandria and Mersa Matruh cities, the Mediterranean seashore is almost completely privately owned. It also rings a bell regarding the privatization of the Red Sea coast and the Sinai Peninsula. The suggestion of this research is that beaches can be leased by hotels or exclusive clubs for a certain number of years. Hotels and houses can be built behind the scenic road/route looking towards the sea. This research is basically concerned with the basic difference in policies. Saving what is remaining from the North coast, the East coast and Sinai Peninsula coasts from being sold to be transformed into private gated communities, thus saving coastal sites for national projects, for future generations and for the sea to remain a public property seen by all citizens and tourists.

It compares between the two approaches, discusses the differences between them, and suggests a revision of approaches for land use planning for the better of future generations, which is a mix between the two approaches.

\section{Dealing with beaches and sea fronts in different parts of the world}

Beaches and sea fronts are the most desired destinations on Earth. All over the world, people want to see the sea and use the beaches. They are among the places where people connect with nature.

In the USA, Kahrl believes that "America's beaches should be open for every citizen because not only is public space good for society, it's good for the environment. Plus, it is an American right. Universal access to the shore dates to an ancient Roman law, and later, an English common law, that granted the water and the land covered by high tide to the people" (Kahrl, 2014).

In the $\mathbf{U K}$, they are trying to find a mixture between both policies, of having some public beaches, and giving the privacy to homeowners on beaches (Country Life, 2008). A different concept is applied; when a property is bought, it means it is bought just for 99-years, never forever. So eventually everything that is sold returns to the Sovereign (the queen or king).

In Greece "The Greek constitution states clearly that the country's shoreline is considered a public good, and Greek citizen have the right to access and use beaches any time they please. However, no 
single person or company has the right to exploit a public beach or block access to any Greek citizen" (Chrysopoulos, 2019).

In Egypt, according to article 45 of the Egyptian constitution version 2014, "The State shall protect its seas, shores, lakes, waterways and natural protectorates. Trespassing, polluting or misusing any of them is prohibited. Every citizen is guaranteed the right of enjoying them. The State shall protect and develop the green space in the urban areas; preserve plant, animal and fish resources and protect those under the threat of extinction or danger; guarantee humane treatment of animals, all according to the law" (The Egyptian Constitution, 2014).

\section{Case Studies}

Two alternatives will be introduced. In alternative one the beach is public, in alternative two the beach is private. Different examples will be introduced to clarify each alternative.

\section{Alternative one}

In this alternative the beach belongs to the state and can be let to be used by the public for a certain entrance fee. The road is close to the sea, approximately $50-156 \mathrm{~m}$, from which the sea can be seen. Sometimes, it is leased to a developer, who prepares it for the public to use in return for a fee but remains the property of the state which makes the alternative sustainable. Alexandria city cornice is an example of this alternative, where the beach is accessed by the public and the road is scenic. Fig. (1) represents alternative number one. Fig. (2) is a layout of the beach of Alexandria city, where only some cafes are leased for a period. Fig. (3) shows Brighton beach in the South of the UK, where the scenic road is parallel to the sea. Fig. (4) is a zoom in on fig. (3), showing the scenic road behind which, the houses get built. Fig. (5) is a map of Greece showing the scenic road from Anavyssos to Athens. In fig. (6), in Greece, the scenic road passes in front of the beach. Fig. (7) is a close up of the scenic road.

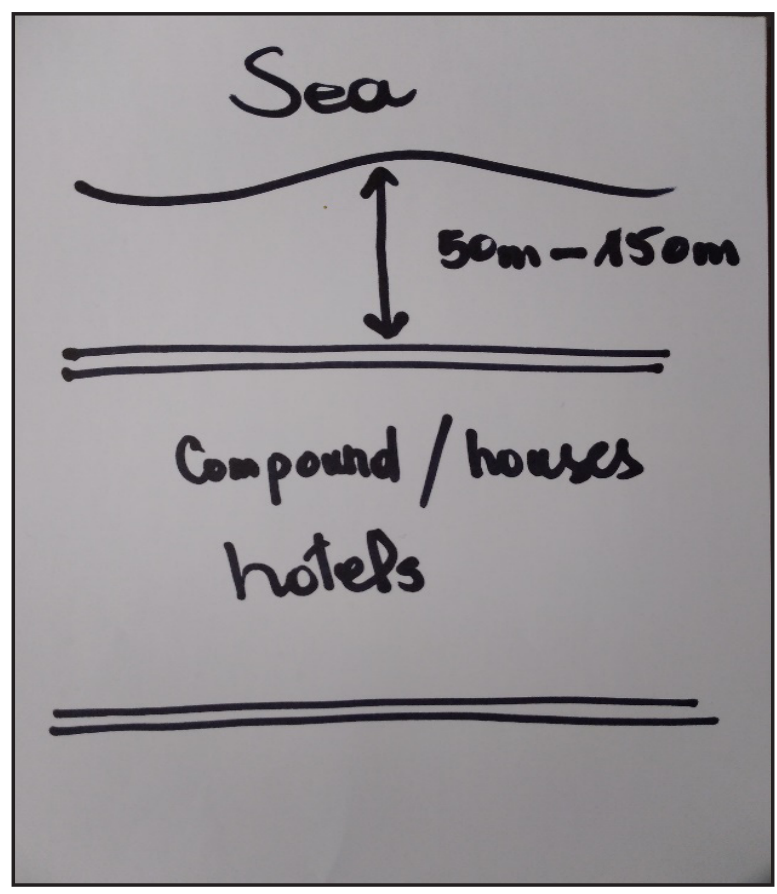

Fig. (1): The Alexandria city alternative. Source: drawing by the author.

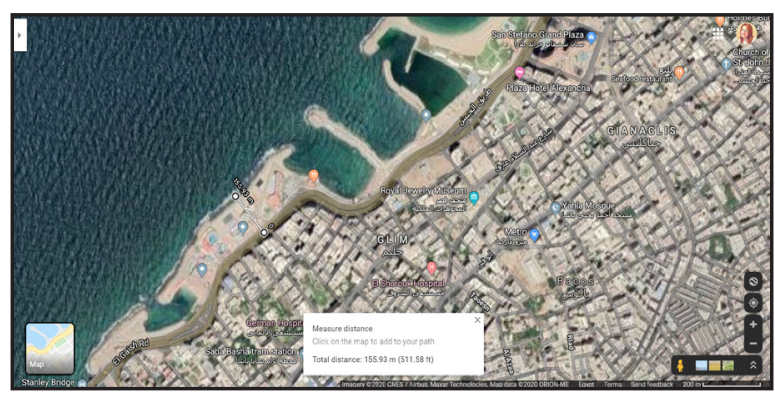

Fig. (2): Alternative 1, shot of Alexandria (the sustainable alternative) cornice where the scenic route is close to the sea. From 50150-m. Source: Google Earth.

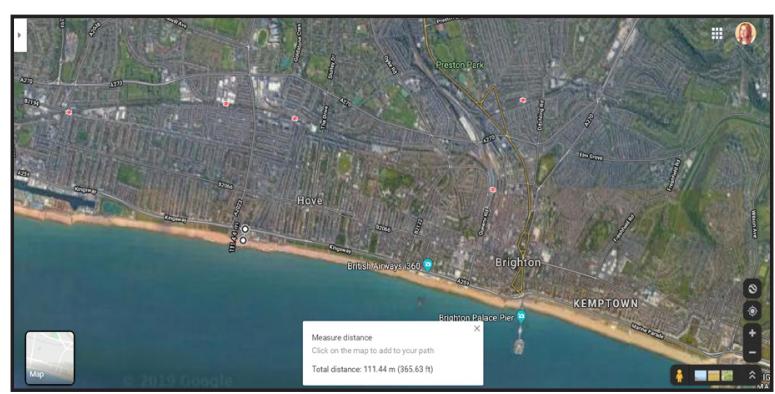

Fig. (3): The South of the UK. The distance between the beach and the road is around $110 \mathrm{~m}$. Source: Google Earth. 


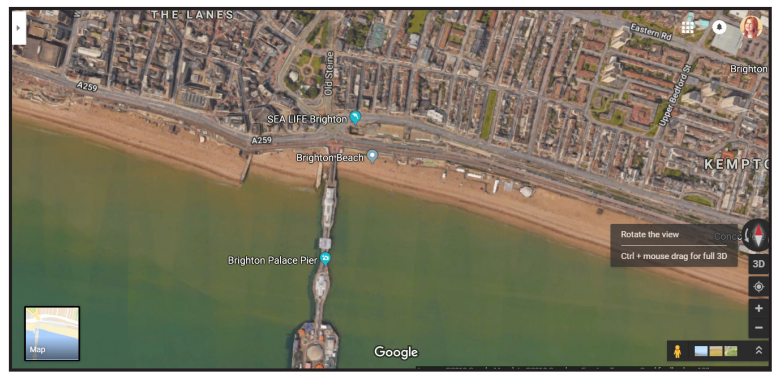

Fig. (4): Brighton beach, showing the scenic route, after which the houses get built. Source: Google Earth.

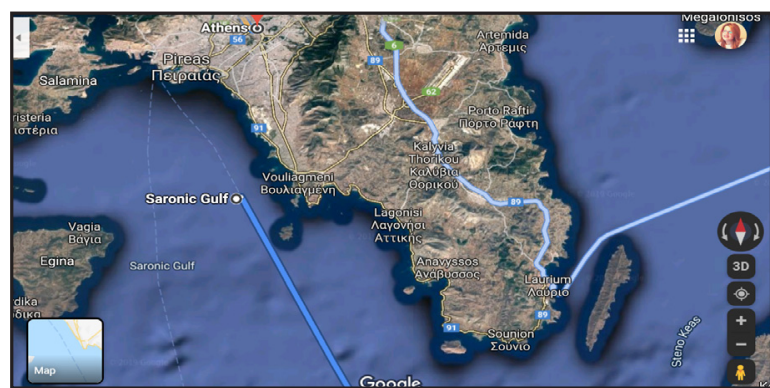

Fig. (5): Greece from Anavyssos to Athens. Source: Google Earth.

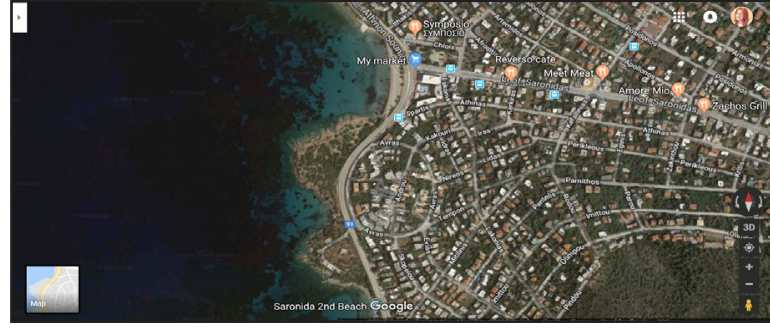

Fig. (6): Greece, the scenic route passes in front of the beach. Source: Google Earth.

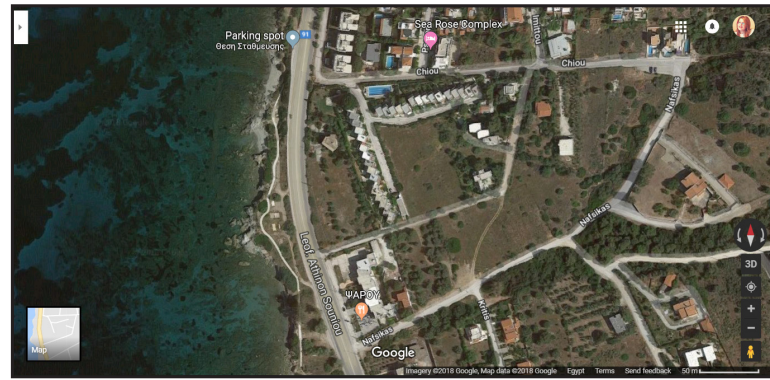

Fig. (7): The scenic route passing in front of the beach is public. Source: Google Earth.

\section{Alternative two}

In this alternative, the road is as far as $1-2 \mathrm{kms}$ from the sea. The land from the road to the sea is sold to a developer who builds it as a compound/ resort for an exclusive number of people who buy a property there. Examples of this alternative are the
North coast case and Sharm El Sheikh City. Fig. (8) represents the idea of alternative two. Fig. (9) shows Marassi and Hacienda Bay compounds in the North coast, where the road is lower than and very far from the sea. Fig. (10) is a close up showing how the road is far from the sea. Fig. (11) is the map showing the distance between the road and the sea ranging from $1 \mathrm{~km}-2.2 \mathrm{kms}$. Fig. (12) shows Sharm El Sheikh City, a case of alternative two. Fig. (13) is a close up of the road and the compound which is $2.26 \mathrm{kms}$ from the sea thus only the compound dwellers can access and see the sea. Fig. (14) shows how the scenic road can be constructed even while the gated compounds exist. Table (1) shows the advantages of the two alternatives.



Fig. (8): Alternative two, the road is far from the sea and the compound dwellings hide the sea from passers-by. Source: drawing by the author.

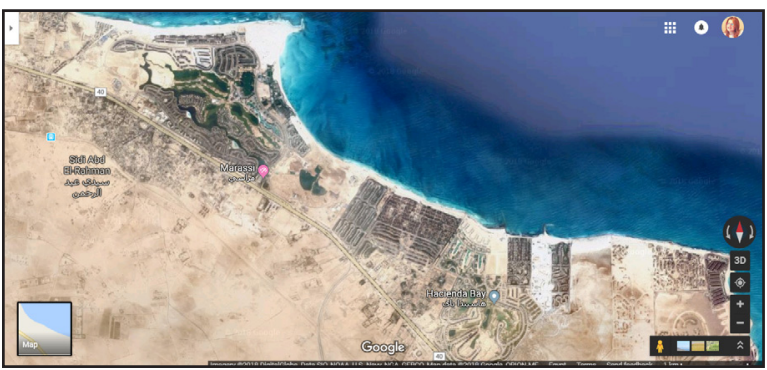

Fig. (9): Marassi North coast compound, and Hacienda bay compound.

The public doesn't get to see the sea even when riding public transport, only the owners and visitors of the compound. Source: Google Earth. 


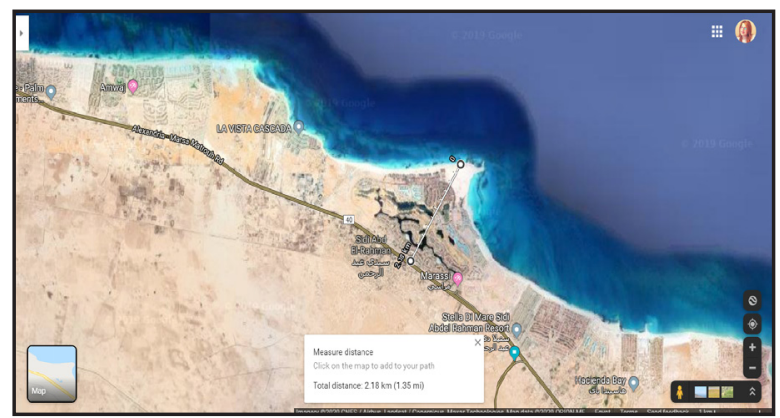

Fig. (10): The road is far away from the beach and there are buildings in between. Source: Google Earth.

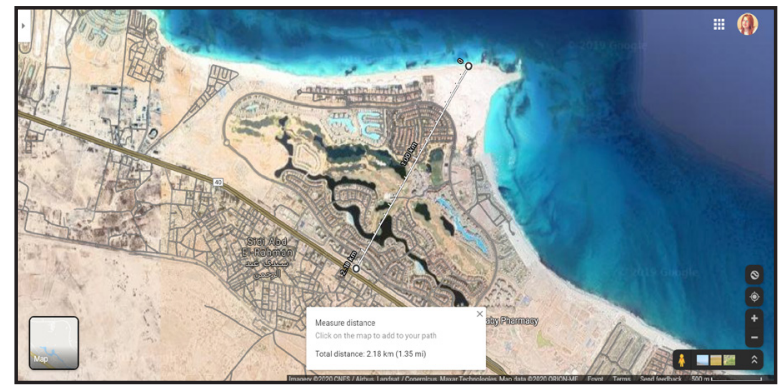

Fig. (11): The map showing the distance between the road and the sea ranging from $1 \mathrm{~km}-2.18 \mathrm{kms}$, Source: Google Earth.

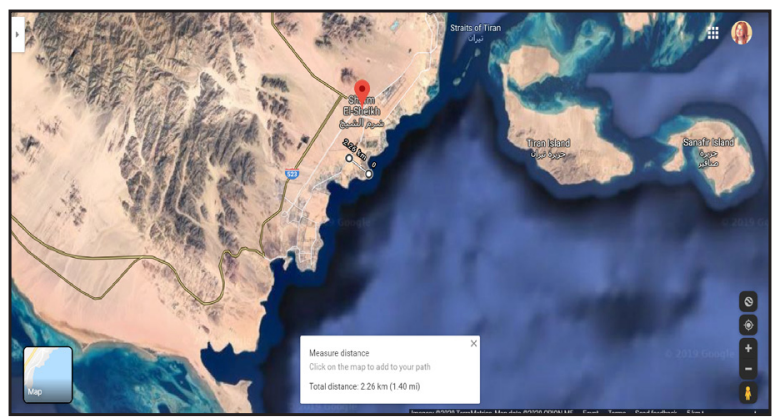

Fig. (12): Sharm ElSheikh City, is a case of alternative two (19).

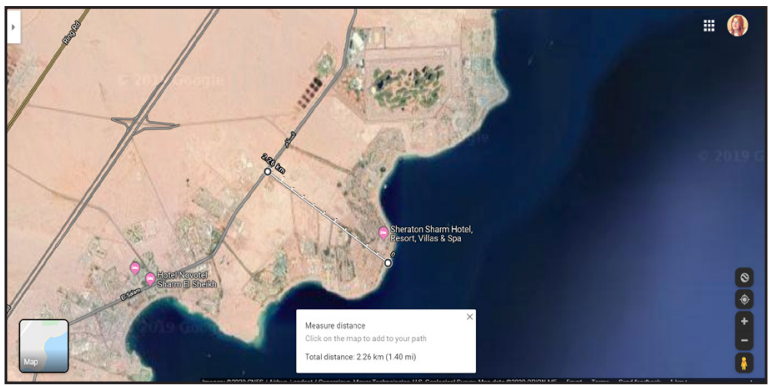

Fig. (13): A close up of the distance between the road and the sea which is around $2.26 \mathrm{kms}$ which deprives the public from seeing the sea, Source: Google Earth.

\section{Properties of the two alternatives}

Table (1): shows the properties of the two alternatives.

\begin{tabular}{|c|c|c|c|}
\hline Index & Property & Alternative one & Alternative two \\
\hline 1. & Ownership & $\begin{array}{c}\text { Remains with the state which preserves } \\
\text { them for all sorts of national projects at } \\
\text { any point in time. }\end{array}$ & Owned by the resort forever. \\
\hline $\mathbf{2 .}$ & Accessibility & $\begin{array}{c}\text { Beaches can be leased by different kinds } \\
\text { of clubs and categories of people so every } \\
\text { citizen and tourist according to their social } \\
\text { class can access the sea. }\end{array}$ & $\begin{array}{c}\text { Beaches belong to an exclusive } \\
\text { number of people. Most citizens } \\
\text { are left out. }\end{array}$ \\
\hline $\mathbf{3 .}$ & Visibility & All citizens can see the sea. & $\begin{array}{c}\text { Only owners of the compounds } \\
\text { and their visitors. }\end{array}$ \\
\hline $\mathbf{4 .}$ & Profits & Profits are not high but continuous. & $\begin{array}{c}\text { Immediate profits by selling the } \\
\text { land to the developer. }\end{array}$ \\
\hline $\mathbf{5 .}$ & Sustainability & $\begin{array}{c}\text { Very sustainable because the land remains } \\
\text { a potential for future generations. }\end{array}$ & $\begin{array}{c}\text { Not sustainable because the } \\
\text { state lost ownership. }\end{array}$ \\
\hline
\end{tabular}

\section{How to turn the situation:}

1. A scenic road can be paved parallel to the sea and the hotels and resorts remain behind it.

2. The land behind the road in the opposite direc- tion can be sold to individuals or private developers, given that the scenic road remains a public property and accessible to all.

3. The land overlooking the sea remains the ownership of the state in case it is needed for any na- 
tional project like the construction of an energy project like a nuclear power plant at any point in time.

Fig. (14) shows how the scenic road (the dark bold line near the sea) can pass across the different gated communities even if their layout designs are not the same where the road doesn't have to be a continuous straight line. Thus, vehicles and public buses can drive through one compound to another depending on the design, provided that the sea can be seen.

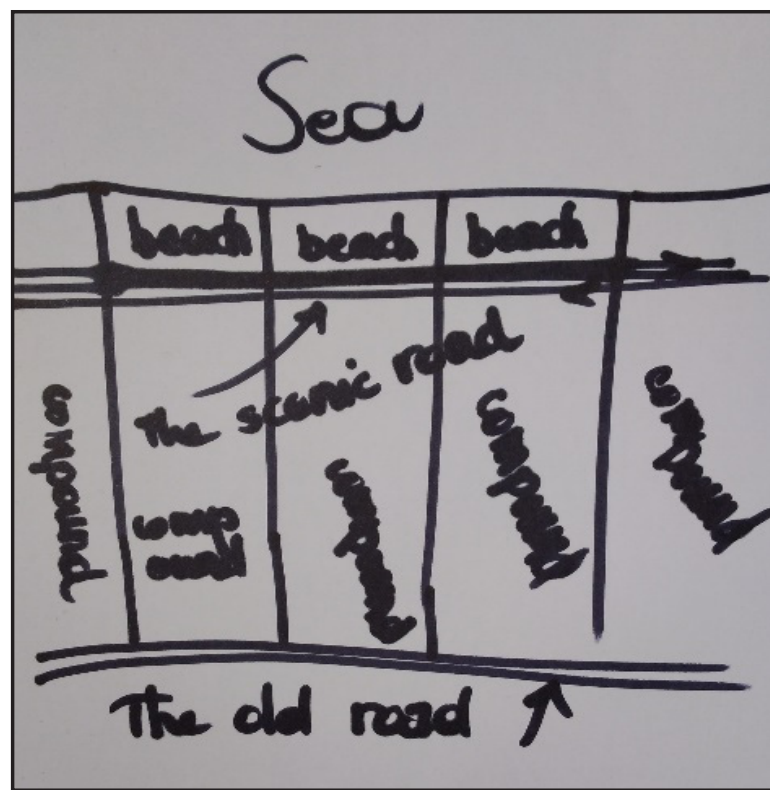

Fig. (14): The scenic road can be constructed even while the gated compounds exist, A freehand drawing by the author.

\section{RESULTS AND DISCUSSIONS}

The Egyptian beaches as long they are, are limited and if the current laws will apply eventually the beaches will end as up as private resorts. Privatizing coasts is not a rational decision to be taken by the state and is against the rights of the public stated in Article 45 of the Egyptian constitution for 2014. This research suggests that, the state ought to revise its strategies of selling the beaches to private developers, as the beaches should belong to all citizens; and because they are resources for national projects that are not yet foreseen nor invented. It also sug- gests that the example of Alexandria cornice should be adopted by Egypt's North coast and East coasts and the Sinai Peninsula. This research suggests a third alternative which suggests a lease for a certain number of years (99 or more), which is adopted by the UK that can be a good idea to get out of the privatization problem.

\section{REFERENCES}

- ASTI Homepage, Collins English Dictionary, https:// www.collinsdictionary.com/dictionary/english/lease.

- Chrysopoulos, P. (2019): How 'Public' are Greek Beaches in Reality?. Greek porter, May 4, 2019. https: //greece.greekreporter.com/2019/05/04/how-publicare-greek-beaches-in-reality/, visited 29.10.2019.

- Constitution of The Arab Republic of Egypt 2014: http://www.sis.gov.eg/Newvr/Dustor-en001.pdf.

- Google meaning: https://www.google.com/search?q $=$ meaning + of + resort + in + english $\&$ oq $=$ meaning + of $+r$ esort $+\&$ aqs $=$ chrome.

- Kahrl, A.W. (2014): Beaches Are an American Right and Environmental Necessity, https://www.nytimes. com/roomfordebate/2014/06/22/should-beach-privatization-be-allowed/beaches-are-an-american-rightand-environmental-necessity.

- Right to roam on British beaches, Country Life, August 7, 2008 https: //www.countrylife.co.uk/property/guides-advice/right-to-roam-on-british-beaches-32818, visited 28.10.2019.

- Wikipedia: https: // en.wikipedia.org/wiki/Scenic _route. (Visited 3.12.2019) 